\title{
Sorption of chlorophenols on geotextile of the geosynthetic clay liners
}

\author{
M'hamed Ahari ${ }^{1^{\dagger}}$, Nathalie Touze-Foltz ${ }^{2}$, Laurent Mazéas ${ }^{2}$ \\ ${ }^{1}$ Laboratory of Research and Development in Engineering Sciences, Faculty of Sciences and techniques, Abdelmalek Essaâdi University, 32000 Al \\ Hoceima, Morocco \\ ${ }^{2}$ National Research Institute of Science and Technology for Environment and Agriculture (IRSTEA), HBAN research unit, 1, rue Pierre-Gilles de \\ Gennes, CS 10030, 92761 Antony Cedex, France
}

\begin{abstract}
Knowledge of organic micropollutant transfers in barrier seal materials from waste storage facilities is limited to volatile organic compounds and phenolic compounds at ambient temperature. This study focused on the sorption of chlorophenols (CPs) from various geotextiles from clay geosynthetics under the influence of temperature. Also to study the impact of the polarity or the amount of CPs adsorbed on geotextiles with the partition coefficient. The effect of various parameters such as contact time, effect of temperature, initial CPs concentration and adsorbent dosage has been carried out in this study. The result obtained is non-linear and the data was calculated for affinity with Freundlich isotherm model. An important observation is that the amount of CPs sorbed on geotextiles increases with a growing number of chlorine atoms, ie increases with the partition coefficient $\left(\log K_{\text {ow }}\right)$. During this study, a decrease in adsorbent properties was observed with the rise in temperature from $23^{\circ} \mathrm{C}$ to $55^{\circ} \mathrm{C}$. The partitioning coefficients for $\mathrm{CPs}$ examined range are from $2.4\left(\mathrm{R}^{2}=0.86\right)$ to $8.4 \mathrm{~mL} / \mathrm{g}\left(\mathrm{R}^{2}=0.90\right)$. Among the $\mathrm{CPs}$ studied, the highest adsorbed quantity was observed for pentachlorophenol with $0.052 \mathrm{~g} / \mathrm{g}$ at $23^{\circ} \mathrm{C}$, this quantity will decrease with the increase in temperature.
\end{abstract}

Keywords: Adsorption, Chlorophenols, Geotextile, Hydrophobicity, Temperature effect

\section{Introduction}

The intensive use of phenol and its derivatives in industrial processes in recent decades has led to widespread pollution of the environment by these toxic compounds [1-4]. Phenolic compounds are very toxic and are among the most dangerous pollutants for human health and the environment, also, most of them are known as potential carcinogens. The toxic and dangerous nature of phenols and their derivatives is well documented [5-9]. The majority of these compounds are known as potential carcinogens. Large-scale coal gasification and carbonization plants generate huge amounts of waste water with high phenolic content [8-10].

Environmental Protection Agency (EPA) regulations in the United States recommend reducing the phenol content in wastewater to less than $1 \mu \mathrm{g} / \mathrm{L}$ compared to the thousands of $\mu \mathrm{g} / \mathrm{L}$ that are often present $[11,12]$. Numerous studies of surface water, including seawater, have shown the presence of chlorophenols (CPs) in these waters at concentrations up to $10 \mathrm{ng} / \mathrm{L}[13,14]$.
CPs has been widely used in industry, resulting in their widespread distribution in the aquatic environment [15-17]. CPs is a group of 19 compounds with substituted chlorines in the phenolic ring formed by chlorination and hydrolysis of chlorobenzenes [18]. Also, have been used since 1920 in various applications, such as wood preservatives, flame retardants, pesticides, in the paper industry and solvents; Many of these compounds are by-products of industrial processes, including the production of pharmaceuticals, pesticides, paints and solvents, and the processing of wood, paper and pulp. These compounds are known to be widespread as components of industrial waste because they have been used in many industrial processes such as the manufacture of plastics, drugs and dyes [18].

Hazardous waste risk assessment of contaminated sites is generally conducted using a four-step process, including (1) hazard identification, (2) exposure assessment, (3) assessment of toxicity and (4) risk characterization [19-20]. The toxicity of CPs depends in particular on the number of chlorines and also on the position
This is an Open Access article distributed under the terms of the Creative Commons Attribution Non-Commercial License (http://creativecommons.org/licenses/by-nc/3.0/) which permits unrestricted non-commercial use, distribution, and reproduction in any medium, provided the original work is properly cited.
Received January 2, 2019 Accepted February 25, 2019

${ }^{\dagger}$ Corresponding author

Email: ahari.mhamed@gmail.com

Tel: +212-539-807-172 Fax: +212-539-807-173

Copyright (C) 2020 Korean Society of Environmental Engineers 
of the chlorine atoms with respect to the $(-\mathrm{OH})$ function of phenol. The possible association between CP-based pesticide production and carcinogenicity has been previously studied by some researchers [21-23].

The transport of a chemical compound in the natural environment strictly depends on the value of the dissociation constant $\left(K_{\mathrm{a}}\right)$ and the partition coefficient $\left(K_{\mathrm{ow}}\right)$ in the octanol-water system. The dissociation constant depends inter alia on the structure of a compound molecule on the number of chlorine atoms in the molecule. Sorption is a major process responsible for sharing toxic compounds between the solid phase of sediments and water [24].

Since our study is limited to the adsorption of CPs, some previously published papers have noted that environmental factors and sorbent characteristics play an important role in controlling the sorption characteristics of soil/sediment compounds. The adsorption of 4-chlorophenol on organophilic bentonite was studied as a function of the concentration and temperature of the solution. Recently, bentonite clay has been used successfully for the adsorption of metal ions and organic compounds [25, 26].

Geosynthetics clay liners (GCLs) are widely used in geoenvironmental applications. A number of studies regarding the use of GCLs in landfills focused on the chemical compatibility of bentonite with leachate or their performance in landfill covers following cation exchange [27]. There have been many recent studies related to the performance of GCLs [28-33]. The adsorption behaviour was affected by several factors such as operating temperature, adsorption time, $\mathrm{pH}$ and pre-treatment of the clay [34]. Among the most cited methods to improve the adsorption capacity, we have the acid treatment and the pilling process [35-36].

The objectives of this paper are to: (a) Evaluate CPs partitioning on the geotextile of GCLs in individual experiments; (b) Fitting two kinetic models to analyse the experimental data; (c) Polarity impact of CPs on adsorption; (d) Investigate the impact of temperature in a range from $23^{\circ} \mathrm{C}$ to $55^{\circ} \mathrm{C}$ on CPs sorption on geotextiles, in order to obtain representative transfer parameters. The parameters obtained for this study are very important later in order to model the potential transfer of CPs through different types of barriers of waste storage facilities on an underlying aquifer.

\section{Materials and Methods}

\subsection{Presentation of Geotextiles Studied}

Two geosynthetic clay coatings representative of the bottom coatings of municipal solid waste landfills were studied corresponding to GCL1 \& GCL2 studied [37]. GCL1 and GCL2, obtained from same manufacturer consist of cover geotextile (GTX1) and carrier geotextile (GTX2). The two GTXs consist of a woven geotextile and nonwoven needled geotextile. The measured masses per unit area of the cover and the carrier geotextiles were $\sim 250 \mathrm{~g} / \mathrm{m}^{2}$ and $\sim 110$ $\mathrm{g} / \mathrm{m}^{2}$, respectively.

\subsection{Chlorophenols}

Six CPs were evaluated 2-chlorophenol (2-CP), 4-chlorophenol (4-CP), 2,4-dichlorophenol (2,4-DCP), 2,4,6-trichlorophenol (2,4,6-TCP), 2,3,5,6-tetrachlorophenol (2,3,5,6-TeCP), and pentachlorophenol (PCP).

Some common chemical properties of the selected chlorophenolic compounds are given in Table 1 [38].

Except for 2-CP, which is a liquid at room temperature, all of the CPs are solids, with their melting points between 33 and $191^{\circ} \mathrm{C}$. Generally, these compounds do not dissolve easily in water, but are very soluble in organic solvents. Although they are classified as acids, mainly those with a high degree of chlorination $\left(\mathrm{p} K_{\mathrm{a}}\right.$ $=4.74$ ), some of them have a high $\mathrm{p} K_{\mathrm{a}}$. The dissociation constant of a compound increases (i.e. its $\mathrm{p} K_{\mathrm{a}}=-\log K_{\mathrm{a}}$ decreases), with the increasing number of chlorine atoms in a molecule, from 2.29 for 2-CP to 5.85 for PCP.

The octanol-water partition coefficient $\left(K_{\text {ow }}\right)$ of the pollutants under study in this paper strongly increases with the number of chlorine atoms whereas the water solubility (hydrophilicity) decreases. Furthermore, the degree of dissociation of CPs increases (indicated by decreasing $\mathrm{p} K_{\mathrm{a}}$ values) with increasing number of chlorine atoms. It is thus expected that the difference in properties of the various CPs results in differences in sorption behaviour on the various components of GCLs tested in this study.

The selection of those CPs was performed taking into account

Table 1. Selected Properties of Chlorophenols Tested

\begin{tabular}{|c|c|c|c|c|c|c|}
\hline Contaminants & 2-CP & 4-CP & 2,4-DCP & 2,4,6-ТCP & 2,3,5,6-ТeCP & PCP \\
\hline \multirow[b]{2}{*}{ Structure } & & $\mathrm{H}$ & $\mathrm{OH}$ & & $\mathrm{OH}$ & \\
\hline & & & & & & \\
\hline & & & & & & \\
\hline Formula & $\mathrm{C}_{6} \mathrm{H}_{5} \mathrm{ClO}$ & $\mathrm{C}_{6} \mathrm{H}_{5} \mathrm{ClO}$ & $\mathrm{C}_{6} \mathrm{H}_{4} \mathrm{Cl}_{2} \mathrm{O}$ & $\mathrm{C}_{6} \mathrm{H}_{3} \mathrm{Cl}_{3} \mathrm{O}$ & $\mathrm{C}_{6} \mathrm{H}_{2} \mathrm{Cl}_{4} \mathrm{O}$ & $\mathrm{C}_{6} \mathrm{Cl}_{5} \mathrm{OH}$ \\
\hline Molecular weight $(\mathrm{g} / \mathrm{mol})$ & 128.56 & 128.56 & 163.00 & 197.45 & 231.89 & 266.34 \\
\hline Solubility at $20^{\circ} \mathrm{C}(\mathrm{g} / \mathrm{L})$ & 27 & 28 & 4.5 & 0.434 & 0.100 & 0.014 \\
\hline $\mathrm{p} K \mathrm{a}$ & 9.37 & 8.52 & 7.90 & 6.00 & 5.02 & 4.74 \\
\hline $\log \mathrm{K}_{\mathrm{ow}}$ & 2.29 & 2.53 & 3.20 & 3.67 & 5.02 & 5.85 \\
\hline Melting point ${ }^{\circ} \mathrm{C}$ & 9.3 & 43.5 & 45 & 69 & 115 & 190 \\
\hline Boiling point ${ }^{\circ} \mathrm{C}$ & 175 & 220 & 210 & 264 & No data & 310 \\
\hline
\end{tabular}


the following criteria: polarity, solubility in water, mobility of pollutants in soils, presence in leachate, and toxicity.

Concentrations of the contaminants $(10 \mu \mathrm{g} / \mathrm{L})$ were identical to the ones in the studies by Ahari et al. [37]. They were selected based on two important points, on the one hand a bibliographic research study to determine the minimum, maximum and average values of CPs concentrations in leachates [39]; and on the other hand on the values limit of detection (LOD) and the limit of quantification (LOQ).

\subsection{Analytical Methods}

A Varian gas chromatography/mass spectrometer GC-MS (trace GC and DSQ, Thermo fischer) equipped with a Combi PAL autosampler (CTC Analytics) allowing automatic SPME extraction. The GC split-splitless injector was operating in the splitless mode. The chromatographic column was a Zebron 5 MS column (5\% phenyl-methyl polysiloxane, Phenomenex, $60 \mathrm{~m}$ length, $0.25 \mathrm{~mm}$ I.D., $0.25 \mu \mathrm{m}$ film thickness). Chromatographic separation was performed using the following temperature programme: (a) $40^{\circ} \mathrm{C}$ for $5 \mathrm{~min}$; (b) ramp one to $115^{\circ} \mathrm{C}$ at $15^{\circ} \mathrm{C} \cdot \mathrm{min}^{-1}$; (c) ramp two to $175^{\circ} \mathrm{C}$ at $3^{\circ} \mathrm{C} \cdot \mathrm{min}^{-1}$; (d) $175^{\circ} \mathrm{C}$ for $5 \mathrm{~min}$; (e) an increase to $250^{\circ} \mathrm{C}$ at $30^{\circ} \mathrm{C} \cdot \mathrm{min}^{-1}$; (f) $250^{\circ} \mathrm{C}$ for $2 \mathrm{~min}$; (g) an increase to $280^{\circ} \mathrm{C}$ at $30^{\circ} \mathrm{C} \cdot \mathrm{min}^{-1}$ and (h) finally $280^{\circ} \mathrm{C}$ for $5 \mathrm{~min}$.

The quantification of CPs was performed using solid phase microextraction/gas chromatography-mass spectrometry (SMPE-GC-MS) using the analytical procedure developed in our laboratory by Limam et al. [40].

The procedure took place in two steps: a derivatization and a headspace extraction. CPs quantification was performed using the single ion monitoring mode. The ions $\mathrm{m} / \mathrm{z} \mathrm{162;196;202;}$ 213; 266; 274 were used, respectively for the 2-CP; 4-CP; 2,4-DCP; 2,4,6-TCP; 2,3,5,6-TeCP and PCP. Then the headspace extraction of target compounds was performed with a $100 \mu \mathrm{m}$ PDMS SPME fiber at $80^{\circ} \mathrm{C}$ for $30 \mathrm{~min}$ with agitation (500 rpm). Afterwards, the SPME fiber was desorbed in the injector at $250^{\circ} \mathrm{C}$ for 5 min. GC/MS analysis was then performed as previously described.

The performance of the GC/MS was checked each time samples were tested by running duplicates, a lab blank, and a known standard sample and was found to be within the $90 \%$ of the target value.

\subsection{Adsorption Procedure}

Duplicate geotextile (GTX) partitioning tests were performed together with one control test (CPs in DDW and no GTX) and one blank test (GTX in DDW and no CPs) at room temperature.

The adsorption tests of CPs on the geotextiles GTX-1 and GTX-2 were carried out in order to quantify the adsorption coefficients $K_{d}$ of the phenolic compounds. The test consists of completely immersing $2 \mathrm{~g}$ of each type of geotextile cut into pieces in solutions with five different concentrations, in 100 $\mathrm{mL}$ glass bottles.

The solid/liquid ratio adopted for our experiments is $1 / 40$, ie $2 \mathrm{~g}$ of geotextile for $80 \mathrm{~mL}$ of the solution containing the pollutants. The solid/liquid ratio adopted in the experiments, is consistent with the ones adopted by Rowe et al. [39] and Ganne et al. [41] in works they performed regarding the sorption of volatile organic compounds (VOCs) on geotextiles.

The experiments were carried out in two stages, first of all determining the time of attaining equilibrium on two geotextiles and two concentrations. First, a kinetic study was done to determine the time to reach equilibrium. Once the equilibrium time was determined, the adsorption tests of different geotextiles were carried out in different solutions at four different concentrations for the determination of isotherms (equilibrium sorption). Indeed all the tests are duplicated. Samples were taken at $\mathrm{t}=0$ to determine the initial concentration of phenols in the solution, followed by sampling at the end of the tests at $t=72 \mathrm{~h}$. All the experiments were carried out in the geosynthetic test laboratory whose temperature is close to $23^{\circ} \mathrm{C}$.

\section{Results and Discussion}

\subsection{Effect of Time of Adsorption}

To determine the time needed to reach equilibrium, a kinetic study was carried out with GTX1 and GTX2. The solutions were immediately sampled after introduction in narrow-neck bottles to determine initial concentrations of CPs in the reaction medium. Subsequently, samples were taken after 2, 4, 6, 24, 48, 72 and $144 \mathrm{~h}$ of contact between the solutions and geotextiles.

Samples were taken using a syringe $5 \mathrm{~mL}$ samples were taken from each vial of $80 \mathrm{~mL}$ at the beginning and the end of the tests and $2 \mathrm{~mL}$ samples were taken from each bottle at intermediate sampling times.

Fig. 1 shows the results obtained. Equilibrium was reached for CPs after $72 \mathrm{~h}$. This time was the testing time adopted in the following experiments performed in order to determine the adsorption isotherms for the two geotextiles, following the procedure previously described in section 2.4. This period is consistent with equilibrium times obtained by Rowe et al. [39] and Ganne et al. [41] regarding the sorption of VOCs on geotextiles.

All the tests, for each geotextile and each concentration were realized in duplicate, in the laboratory where the temperature is $23^{\circ} \mathrm{C}$.

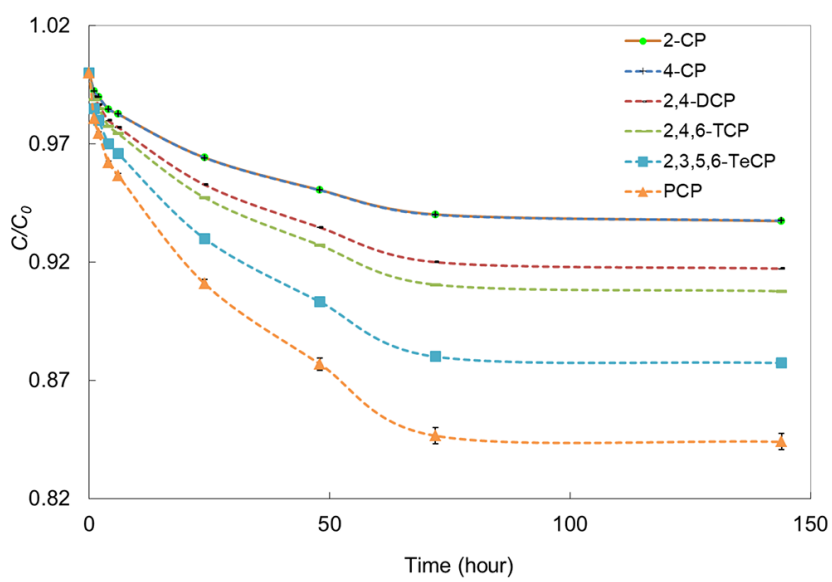

Fig. 1. Adsorption of chlorophenols by GTX1. 


\subsection{Adsorption Isotherm}

Once the equilibrium time was determined, the adsorption tests of the two geotextiles were carried out in different solutions at four different concentrations for the determination of isotherms (equilibrium sorption), using 32 vials in total. Indeed all the tests are duplicated. Samples were taken immediately after injection to determine the initial concentration of CPs in the solution, followed by sampling at the end of the tests at $\mathrm{t}=72 \mathrm{~h}$.

The experimental results obtained for the determination of the adsorption parameters concerning the geotextiles are presented in the form of isotherms in Fig. 2 for GTX1. Sorption isotherms are non-linear contrarily to what was observed in the case of VOCs $[39,41]$.

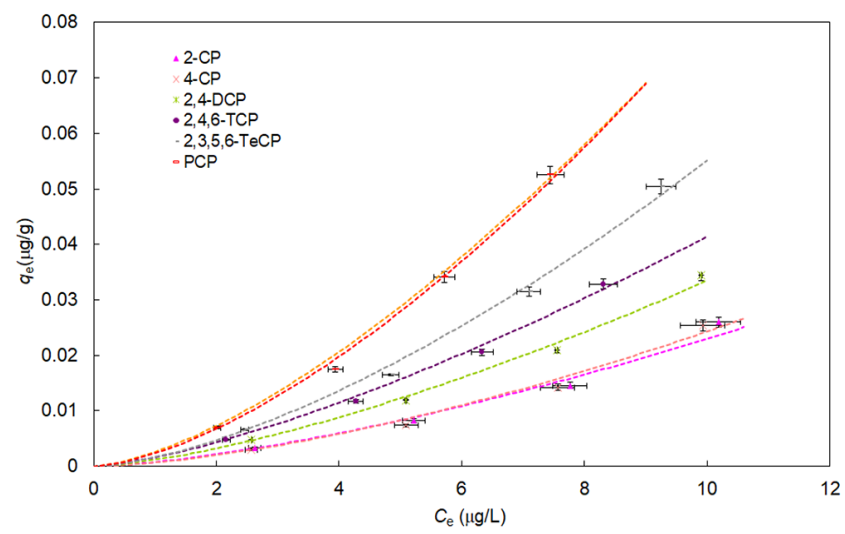

Fig. 2. Results of batch adsorption tests for GTX1 at $23^{\circ} \mathrm{C}$.

The linear and Freundlich model described by Eq. (1) and Eq. (2), respectively, therefore were used to determine the sorption coefficient:

$$
\begin{gathered}
q_{e}=K_{\mathrm{F}} C_{\mathrm{e}}^{1 / n \backslash} \\
q_{e}=K_{\mathrm{d}} C_{\mathrm{e}} \backslash
\end{gathered}
$$

Where: $K_{d}$ is defined as the distribution coefficient in the linear isotherm. $q_{\mathrm{e}}$ and $C_{\text {eq }}$ are the concentration in the solid in $\mu \mathrm{g} / \mathrm{g}$ and the equilibrium solute concentration in $\mu \mathrm{g} / \mathrm{mL}$, respectively, $K_{\mathrm{F}}$ represents the sorption capacity, and $1 / n$ is related to the energy distribution of the sorption sites.

The amount of each phenolic compound adsorbed at equilibrium, $q_{e}$, was calculated using Eq. (3).

$$
q_{e}=\left(C_{0}-C_{\text {eq }}\right) \times V / W
$$

Where: $C_{0}$ and $C_{\text {eq }}(\mu \mathrm{g} / \mathrm{L})$ are the liquid-phase concentrations of each organic compound at initial and equilibrium, respectively, $V$ is the volume of the solution (L), and $W$ is the masse of dry adsorbent used (g).

The linear form of the Freundlich isotherm model is given by the following Eq. (4):

$$
\log q_{e}=K_{\mathrm{F}}+(1 / \mathrm{n}) \log C_{e}
$$

The values of $K_{\mathrm{F}}$ and $1 / n$ can be obtained from the intercept and slope, respectively, of the linear plot of experimental data of $\log q_{\mathrm{e}}$ versus $\log C_{\mathrm{e}}$ as shown in Fig. 3.

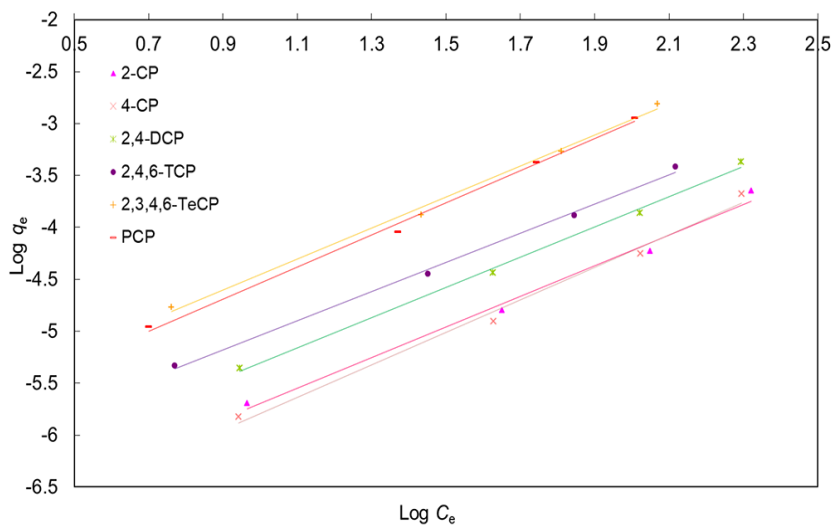

Fig. 3. Freundlich isotherms for chlorophenols adsorption on GTX1 at temperature of $23^{\circ} \mathrm{C}$.

Synthesis of sorption coefficient $K_{d}$ in our case CPs allowed us on the one hand to have a comparison with the VOC sorption expressed in $K_{\mathrm{d}}$ in different literatures, and on the other hand to have a simpler evaluation synthesis of the sorption as a function of the temperature (section 3.4).

Thus, the synthesis of the adsorption parameters of the different CPs calculated for the various geotextiles. The results obtained for linear and Freundlich approaches are presented in Table 2. The best correlations were obtained for the Freundlich equation.

The coefficient of determination, $R^{2}$ values, which are a measure of goodness-of-fit, show that both the Freundlich isotherm models can sufficiently, describes the adsorption data well for all six CPs studied. The concentrations measured during these experiments were not corrected, since the blanks tests did not reveal any sorption of the CPs on the glass.

When the Freundlich model is applied, we find $K_{\mathrm{F}}$ and $1 / n$ values ranging from 7.62 to $97.53 \mathrm{mg}^{1-1 / \mathrm{n}} \mathrm{mL}^{1 / \mathrm{n}} \mathrm{g}^{-1}$ and from 1.28 to 1.74 , respectively. In this case, it is observed that there is a considerable difference between the woven geotextiles and the needled geotextiles for certain CPs. It should be noted that the coefficients of determination show that the adjustment of Freundlich is the most reliable. Indeed, the evolution of the linear partition coefficients with the contaminants always has the same tendency for the two geotextiles; it is not obvious for the Freundlich settings. It should also be noted that PCP has the highest adsorption tendency vis-a-vis the other pollutants studied.

$K_{\mathrm{d}}$ expresses the proportionality between the mass of contaminant removed from solution and the concentration in solution. The values of $K_{\mathrm{d}}$ partition coefficients of different phenols for different geotextiles are 2.7 to $8.9 \mathrm{~mL} / \mathrm{g}$ and there is a slight difference between woven geotextiles and needled geotextiles. For comparison, these values remain low compared to VOCs. As an example, the adsorption coefficient $\left(K_{d}\right.$ in $\left.\mathrm{mL} / \mathrm{g}\right)$ for benzene and toluene are: 32.2 and 97.4 from Rowe et al. [39], 41 and 135 from Ganne et al. [41]. 
Table 2. Synthesis of Partitioning Coefficients for the Geotextiles of the Chlorophenols under Study at $23^{\circ} \mathrm{C}$

\begin{tabular}{|c|c|c|c|c|c|c|c|c|c|c|}
\hline & \multicolumn{5}{|c|}{ GTX1 } & \multicolumn{5}{|c|}{ GTX2 } \\
\hline & \multicolumn{3}{|c|}{ Freundlich } & \multicolumn{2}{|c|}{ Linear } & \multicolumn{3}{|c|}{ Freundlich } & \multicolumn{2}{|c|}{ Linear } \\
\hline & $\mathbf{K}_{\mathrm{F}}$ & $1 / n$ & $\mathbf{R}^{2}$ & $K_{d}$ & $\mathbf{R}^{2}$ & $\mathbf{K}_{\mathbf{F}}$ & $1 / n$ & $\mathbf{R}^{2}$ & $\mathbf{K}_{\mathbf{d}}$ & $\mathbf{R}^{2}$ \\
\hline 2-CP & 20.03 & 1.47 & 0.98 & 2.90 & 0.88 & 13.59 & 1.41 & 0.96 & 2.70 & 0.86 \\
\hline 4-СР & 30.59 & 1.55 & 0.98 & 3.00 & 0.87 & 90.32 & 1.78 & 0.97 & 2.80 & 0.83 \\
\hline 2,4-DCP & 26.59 & 1.45 & 0.99 & 4.00 & 0.90 & 7.62 & 1.24 & 0.97 & 3.00 & 0.86 \\
\hline 2,4,6-ТCP & 26.15 & 1.40 & 0.99 & 4.50 & 0.92 & 12.13 & 1.28 & 0.97 & 3.50 & 0.89 \\
\hline 2,3,5,6-ТеСР & 60.40 & 1.52 & 0.99 & 6.40 & 0.90 & 47.57 & 1.48 & 0.99 & 5.90 & 0.91 \\
\hline PCP & 97.53 & 1.54 & 0.99 & 8.40 & 0.90 & 61.79 & 1.47 & 0.99 & 7.60 & 0.92 \\
\hline
\end{tabular}

\subsection{Effect of Hydrophobicity on Adsorption}

An important observation is that the amount of CPs sorbed on geotextiles increases with an increasing number of chlorine atoms. Fig. 4 shows the relationship between the partition coefficient (log $\left.K_{\mathrm{ow}}\right)$ of CPs and amount sorbed at equilibrium $\left(q_{\mathrm{e}}\right)$ by the two different geotextiles. In the case of CPs polarity appears to be connected with the differences in adsorption.

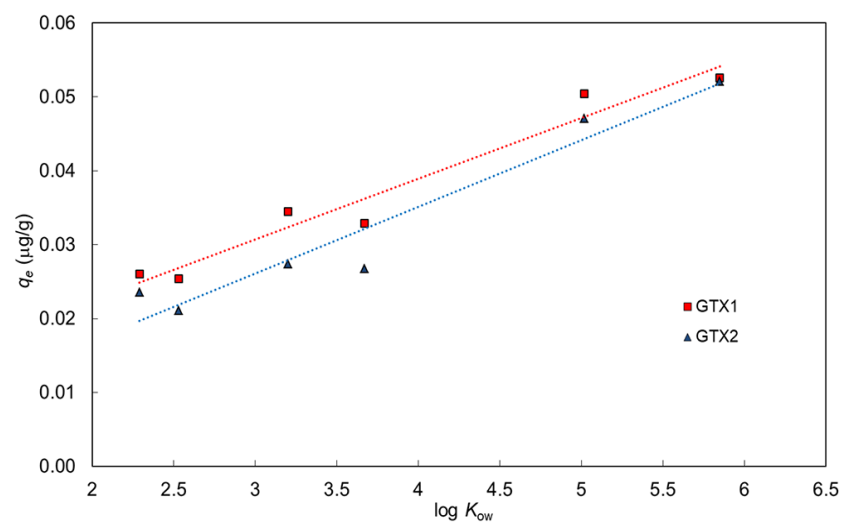

Fig. 4. Relationship between the partition coefficient (log Kow) of chlorophenols and amount adsorbed at equilibrium by the two geotextiles.

It does thus seem that the partitioning coefficient decreases as the hydroxyl group, hydrophilic (due to its hydrogen bonds) tends to make the molecule soluble. Indeed, while the solubility of benzene is only $1.78 \mathrm{~g} / \mathrm{L}$ at $20^{\circ} \mathrm{C}$ the one of phenol is $90 \mathrm{~g} / \mathrm{L}$.

For example for GTX1, the values of the partition coefficients $K_{\mathrm{d}}$ of the CPs increase with the increase of chlorine number on the phenol of $2.90,3.00,4.00,4.50,6.40$ to 8.40 for 2-CP, 4-CP, 2,4-DCP, 2,4,6-TCP, 2,3,5,6-TeCP and PCP, respectively (Table 2).

Also in this figure, two different trends can be seen, one for the nonwoven needle-punched geotextile GTX1, and the other for the woven geotextile GTX2.

\subsection{Effect of Temperature on CPs Adsorption}

The objective of this study is to investigate the impact of temperature in a range from $23^{\circ} \mathrm{C}$ to $55^{\circ} \mathrm{C}$ on the sorption of CPs on geotextiles, in order to obtain representative transfer parameters. The first ex- periment was carried out at the geosynthetic test laboratory whose temperature is close to $23^{\circ} \mathrm{C}$, while the 2 nd and 3rd experiments were carried out in the laboratory in an oven at $35^{\circ} \mathrm{C}$ and $55^{\circ} \mathrm{C}$, respectively. The experimental results obtained for the determination of the adsorption parameters of CPs calculated for the two geotextiles at $35^{\circ} \mathrm{C}$ and $55^{\circ} \mathrm{C}$ are shown in Table S1.

It is noted that in a linear approximation of the experimental results, the values of the partition coefficients $K_{\mathrm{d}}$ of CPs are 2.4 and $8.4 \mathrm{~mL} / \mathrm{g}$ for GTX1 and of 2.3 and 7.6 for GTX2 at $35^{\circ} \mathrm{C}$ and $55^{\circ} \mathrm{C}$, respectively. We observed a slight decrease in $K_{d}$ when the temperature increases which is consistent with the results presented in the literature for VOCs [42-43].

When the Freundlich model is applied, we find $K_{\mathrm{F}}$ and $1 / \mathrm{n}$ values at $35^{\circ} \mathrm{C}$ ranging from 5.62 to 117.77 and from 1.25 to 1.59 , respectively and at $55^{\circ} \mathrm{C} K_{\mathrm{F}}$ values ranging from 7.71 to 83.37 and $1 / n$ values from 1.47 to 1.54 .

Fig. 5 clearly shows the impact of the temperature on the adsorption of chlorophenols on the geotextils. The evolution of equilibrium absorption of chlorophenols by both geotextil was affected by temperature. It has indeed been observed, a decrease in adsorbent properties with the increase in temperature from $23^{\circ} \mathrm{C}$ to $55^{\circ} \mathrm{C}$. This effect, of course, would have inverse effects on the diffusive transfer through the geosynthetic clay liners, ie, the temperature increases the diffusive transfers. The decrease of adsorption capacity with the increased in temperature indicated that the adsorption of CPs onto geotextil is exothermic in nature.

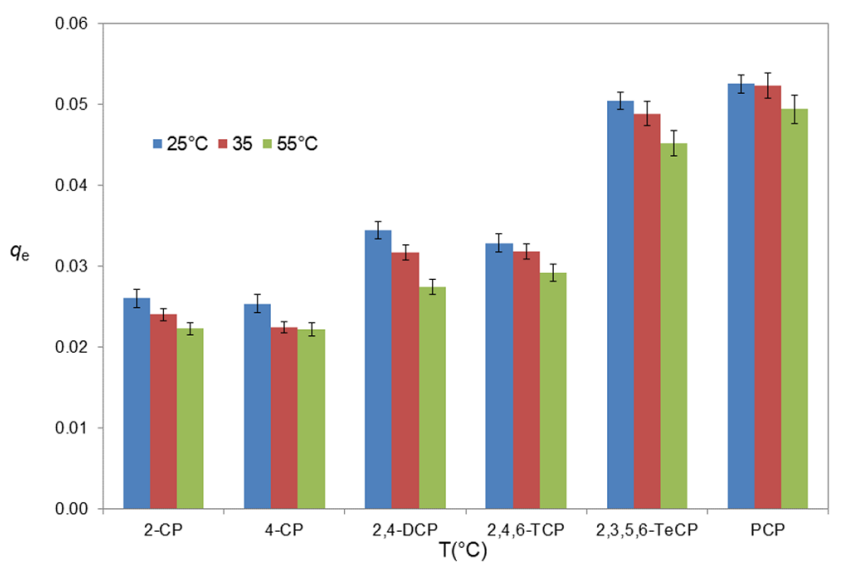

Fig. 5. Effect of temperature on chlorophenols adsorption onto GTX1. 
A similar trend was also observed by Bilgili with 4-chlorophenol adsorption by XAD-4 resin [44] and by Hameed on Trichlorophenol adsorption onto activated clay [42]. Rowe et al. [39] also demonstrated that for VOCs, temperature had an impact on both diffusion coefficient and sorption in geosynthetic clay liners at temperatures between 7 and $22^{\circ} \mathrm{C}$. Indeed, a decrease of the absorption coefficients with the increase of the temperature is observed for the VOCs. The decrease in adsorption when the temperature increases, can be explained by the weakening of the forces between the adsorbent and the adsorbed compounds [42, 43].

For example, in the this study, in the case of GTX1, an adsorption towards 2,4-dichlorophenol of the order of 0.0344, 0.0317 and 0.0274 $\mu \mathrm{g} / \mathrm{g}$ is obtained at temperatures of 23,35 and $55^{\circ} \mathrm{C}$, respectively, confirming the exothermic nature of the adsorption process. The following Table S2 represents the equilibrium adsorbed quantity for the rest of the CPs, $q_{\mathrm{e}}$, by the two geotextiles. In this study, it was also observed that the amount of CPs sorbed on geotextiles increased with increasing numbers of chlorine atoms at either $35^{\circ} \mathrm{C}$ or $55^{\circ} \mathrm{C}$. At the present time, the sorption structure and sorption mechanism of CPs onto geotextiles are not elucidated. Décány [45-48], Park [49-50] and other researchers [7, 51] have widely studied the sorption properties of clay minerals for organic chemicals and surfactants. They have the effect of hydrophobic properties of surface, and developed the sorption model. The loaded surfactants created the organic solvent-like hydrophobic phase and the interaction can be described as partition mechanism, resulting in a strong attraction of CPs molecules with the organoclays through Van der Waals interaction. In addition, there are several possible mechanisms for the adsorption of CPs, including electrostatic interaction, donor-acceptor complex formation, and hydrogen bonding.

\section{Conclusions}

Results of sorption tests of various CPs (2-CP, 4-CP, 2,4-dichlorophenol, 2,4,6-TCP, 2,3,5,6-TeCP, PCP) on constitutive geotextiles of GCLs were presented in this paper. The first result obtained is that the sorption isotherms obtained are non-linear. The sorbed amounts of CPs increase with increase in contact time, reaching a maximum value after $72 \mathrm{~h}$. The Freundlich isotherm was demonstrated to provide the best correlation for the adsorption of CPs.

In terms of hydrophobicity, an important observation is that the amount of CPs sorbed on geotextiles increases with a growing number of chlorine atoms, ie increases with the partition coefficient $\left(\log K_{\text {ow }}\right.$ ). For example for GTX1, the values of the partition coefficients $K_{\mathrm{d}}$ of the CPs increase with the increase of chlorine number on the phenol of 2.90 for 2-CP to 8.40 for PCP. Tending to show that the partitioning coefficient decreases as the hydroxyl group tends to make the molecule more soluble. As far as the Freundlich constants are concerned, alight difference was observed between nonwoven needle-punched geotextiles and woven geotextiles. This latest result is logical as the less polar the contaminant is, the less it is soluble in water. This results in a potential for a larger adsorption on the geotextile.

During this study, a decrease in adsorbent properties was observed with the increase in temperature from $23^{\circ} \mathrm{C}$ to $55^{\circ} \mathrm{C}$. It is noted that in a linear approximation of the experimental results, the values of the partition coefficients $K_{\mathrm{d}}$ of 2,4-CP for example are $4.0 ; 3.7$ and $2.7 \mathrm{~mL} / \mathrm{g}$ for GTX 1 at $23^{\circ} \mathrm{C} ; 35^{\circ} \mathrm{C}$ and $55^{\circ} \mathrm{C}$, respectively. The decrease of adsorption capacity with the increased in temperature indicated that the adsorption of CPs onto geotextile is exothermic in nature.

In this study, it was also observed that the amount of CPs sorbed on geotextiles increased with increasing numbers of chlorine atoms at either $23^{\circ} \mathrm{C}$ or $55^{\circ} \mathrm{C}$. If we take the same case of 2,4-DCP, we observe that an adsorption towards of the order of $0.0344,0.0317$ and $0.0274 \mu \mathrm{g} / \mathrm{g}$ is obtained at temperatures of 23,35 and $55^{\circ} \mathrm{C}$, respectively. This effect obviously would have inverse effects on the diffusive transfer through the GCLs.

\section{Acknowledgments}

The study presented in this paper was funded RGC\&U (C2D2) for the Duragéos research program labelled by Axelera and Advancity which partners were IFSTTAR, IRSTEA, LTHE, ENTPE, PIMM Arts et Métiers ParisTech, Suez-Environment and Veolia Propreté.

\section{References}

1. Khan Z, Anjaneyulub Y. Influence of soil components on adsorption-desorption of hazardous organics-development of low cost technology for reclamation of hazardous waste dumpsites. J. Hazard. Mater. 2005;118:161-169.

2. Fishbein L. An overview of environmental and toxicological aspects of aromatic hydrocarbons. II. Toluene. Sci. Total Environ. 1985;42:267-288.

3. Merain E, Zander M, Volatile aromatics. In: Hutzinger O, eds. The hand book of environmental chemistry. Part B. Anthropogenic Compounds, vol. 3. New York: Springer-Verlag; 1982. p. 89-116 \& 117-161.

4. Choi JS, Koduru JR, Lingamdinne LP, Yang JK, Chang YY. Effective adsorptive removal of 2,4,6-trinitrotoluene and hexahydro-1,3,5-trinitro-1,3,5-triazine by pseudographitic carbon: Kinetics, equilibrium and thermodynamics. Environ. Chem. 2018;15:100-112.

5. Wang G, Zhang S, Hua Y et al. Phenol and/or $\mathrm{Zn}^{2+}$ adsorption by single- or dual-cation organomontmorillonites. Appl. Clay Sci. 2017;140:1-9.

6. Koduru JR, Lingamdinne LP, Singh J, Choo KH. Effective removal of bisphenol A (BPA) from waterusing a goethite/activated carbon composite. Process Saf. Environ. 2016;103:87-96.

7. Park HS, Koduru JR, Choo KH, Lee B. Activated carbons impregnated with iron oxide nanoparticles for enhanced removal of bisphenol A and natural organic matter. J. Hazard. Mater. 2015;286:315-324.

8. Uçar S, Evcin A, Uçar M, Alibeyli R, Majdan M. Removal of phenol and chlorophenols from aquatic system using activated clinoptilolite. Hacettepe J. Biol. Chem. 2015;43:235-249.

9. Bayramoğlu G, Arıca MY. Enzymatic removal of phenol and p-chlorophenol in enzyme reactor: Horseradish peroxidase im- 
mobilized on magnetic beads. J. Hazard. Mater. 2008;156: 148-155.

10. Lin SH, Juang RS. Adsorption of phenol and its derivatives from water using synthetic resins and low-cost natural adsorbents: A review. J. Environ. Manage. 2009;90:1336-1349.

11. Denizli A, Özkan G, Uçar M. Removal of chlorophenols from aquatic systems with dye-affinity microbeads. Sep. Purif. Technol. 2001;24:255-262.

12. Tang D, Zheng Z, Lin K, Luan J, Zhang J. Adsorption of p-nitrophenol from aqueous solutions onto activated carbon fiber. J. Hazard. Mater. 2007;143:49-56.

13. Asplund G, Grimvall A. Organohalogens in nature. Environ. Sci. Technol. 1991;25:1346-1350.

14. Grimvall A, Laniewski K, Borén H, Jonsson S, Kaugare S. Organohalogens of natural or unknown origin in surface water and precipitation. Toxicol. Environ. Chem. 1994;46:183-190.

15. Fan HT, Zhao CY, Liu S, Shen H. Adsorption characteristics of chlorophenols from aqueous solution onto graphene. J. Chem. Eng. Data 2017;62:1099-1105.

16. Dąbrowski A, Podkosćielny P, Hubicki Z, Barczak M. Adsorption of phenolic compounds by activated carbona critical review. Chemosphere 2005;58:1049-1070.

17. Czaplicka M. Sources and transformations of chlorophenols in the natural environment. Sci. Total Environ. 2004;322:21-39.

18. Estevinho BN, Ratola N, Alves A, Santos L. Pentachlorophenol removal from aqueous matrices by sorption with almond shell residues. J. Hazard. Mater. 2006;137:1175-1181.

19. Cha DK, Song JS, Sarr D, Kim BJ. Hazardous waste treatment technologies. Water Environ. Res. 1996;4:575-586.

20. Baciocchi R, Boni MR, Lavecchia R. Modeling of chlorophenols competitive adsorption on soils by means of the ideal adsorbed solution theory. J. Hazard. Mater. 2005;118:239-246.

21. Woods JS, Polissar L, Severson RK. Soft tissue sarcoma and non-Hodgkin's lymphoma in relation to phenoxyherbicide and chlorinated phenol exposure in western Washington. J. Nat. Cancer Inst. 1987;78:899-910.

22. Hoar SK, Blair A, Holmes FF. Agricultural herbicide use and risk of lymphoma and soft-tissue sarcoma. JAMA 1986;256: 1141-1147.

23. Eriksson M, Hardell L, Berg N, Moller T, Axelson O. Soft-tissue sarcoma and exposure to chemical substances: A casereference study. Br. J. Ind. Med. 1981;38:27-33.

24. Cornelissen G, Gustafsson O, Bucheli TD, Jonker MTO, Koelmans AA, Van Noort PCM. Extensive sorption of organic compounds to black carbon, coal, and kerogen in sediments and soils: Mechanisms and consequences for distribution, bioaccumulation, and biodegradation. Environ. Sci. Technol. 2005;39:6881-6895.

25. Naseem R, Tahir SS. Removal of $\mathrm{Pb}$ (II) from aqueous/acidic solutions by using bentonite as an adsorbent. Water Res. 2001;35:3982-3986

26. Tahir H, Uzma H, Sultan M, Jahanzeb Q. Batch adsorption technique for the removal of malachite green and fast green dyes by using montmorillonite clay as adsorbent. Afr. J. Biotechnol. 2010;9:8206-8214.

27. Touze-Foltz N, Lupo J, Barroso M. Geoenvironmental applications of geosynthetics. In: Proceedings of the EuroGeo 4, the
Fourth European Geosynthetics Conference; 7-10 September 2008; Edinburgh, United Kingdom.

28. Acikel AS, Singh RM, Bouazza A, Gates WP, Rowe RK. Applicability and accuracy of the initially dry and initially wet contact filter paper tests for matric suction measurement of geosynthetic clay liners. Geotechnique 2015;65:780-787.

29. Bannour H, Touze-Foltz N. Flow-rate measurements in meter-size multicomponent geosynthetic clay liners. Geosynth. Int. 2015;22:70-77.

30. Brachman RWI, Rentz A, Rowe RK, Take WA. Classification and quantification of downslope erosion from a geosynthetic clay liner (GCL) when covered only by a black geomembrane. Can. Geotech. J. 2015;52:395-412.

31. Liu Y, Bouazza A, Gates WP, Rowe RK. Hydraulic performance of geosynthetic clay liners to sulfuric acid solutions. Geotext. Geomembr. 2015;43:14-23.

32. Puma S, Dominijanni A, Manassero M, Zaninetta L. The role of physical pretreatments on the hydraulic conductivity of natural sodium bentonites. Geotext. Geomembr. 2015;43:263-271.

33. Saheli PT, Rowe RK. Sorption and diffusion of bisphenol-A (BPA) through a geosynthetic clay liner (GCL). Geotext. Geomembr. 2016;44:731-738.

34. Banat FA, AI-Bashir B, AI-Asheh S, Hayajneh O. Adsorption of phenol by bentonite. Environ. Pollut. 2000;107:391-398.

35. Koh SM, Dixon B. Preparation and application of organo-minerals as sorbents of phenol, benzene and toluene. Appl. Clay Sci. 2001;18:111-122.

36. Lawrence MAM, Kukkadapu RK, Boyd SA. Adsorption of phenol and chlorinated phenols from aqueous solution by tetramethylammonium- and tetramethylphosphonium-exchanged, montmorillonite. Appl. Clay Sci. 1998;13:13-20.

37. Ahari M, Touze-Foltz N, Mazéas L, Guenne A. Quantification of the adsorption of phenolic compounds on the geotextile and bentonite components of four geosynthetic clay liners. Geosynth. Int. 2011;18:322-331.

38. Touze-Foltz N, Ahari M, Mendes M, Barral C, Gardoni M, Mazéas L. Diffusion of phenolic compounds through an HDPE geomembrane. Geotech. Eng. 2012;43:19-29.

39. Rowe RK, Mukunoki T, Sangam HP. BTEX diffusion and sorption for a geosynthetic clay liner at two temperatures. ASCE J. Geotech. Geoenviron. Eng. 2005;131:1211-1221.

40. Limam I, Guenne A, Driss M, Mazeas L. Simultaneous determination of phenol, methylphenols, chlorophenols and bisphenol-A by headspace solid-phase microextraction-gas chromatography-mass spectrometry in water samples and industrial effluents. Int. J. Environ. Anal. Chem. 2010;90:230-244.

41. Ganne A, Touze-Foltz N, Mazeas L, Guenne A, Epissard J. Experimental determination of sorption and diffusion of organic pollutants through GCLs. In: Proceedings of the EuroGeo 4, the Fourth European Geosynthetics Conference; 7-10 September 2008; Edinburgh, United Kingdom.

42. Hameed BH. Equilibrium and kinetics studies of 2,4,6-trichlorophenol adsorption onto activated clay. Colloid. Surf. A Physicochem. Eng. Asp. 2007;307:45-52.

43. Zheng $\mathrm{H}$, Wang $\mathrm{Y}$, Zheng $\mathrm{Y}$, Zhang $\mathrm{H}$, Liang $\mathrm{S}$, Long $\mathrm{M}$. Equilibrium, kinetic and thermodynamic studies on the sorption of 4-hydroxyphenol on Cr-bentonite. Chem. Eng. J. 2008;143 
117-123.

44. Bilgili MS. Adsorption of 4-chlorophenol from aqueous solutions by xad-4 resin: isotherm, kinetic, and thermodynamic analysis. J. Hazard. Mater. 2006;137:157-164.

45. Dékány I, Szánto E, Nagy LG. Sorption and immersional wetting on clay minerals having modified surface. Part I. Surface properties of nonswelling clay mineral organocomplexes. J. Colloid Interface Sci. 1985;103:321-331.

46. Dékány I, Szánto F, Nagy LG. Sorption and immersional wetting on clay minerals having modified surface. Part II. Interlamellar sorption and wetting on organic montmorillonites. J. Colloid Interface Sci. 1986;109:376-384.

47. Dékány I, Szánto F, Weiss A, Lagaly G. Interactions of hydrophobic layer silicates with alcohol-benzene mixtures I. Adsorption isotherms. Ber. Bunsenges. Phys. Chem. 1986;90:
422-427.

48. Dékány I, Szánto F, Weiss A, Lagaly G. Interactions of hydrophobic layer silicates with alcohol-benzene mixtures II. Structure and composition of the adsorption layer. Ber. Bunsenges. Phys. Chem. 1986;90:427-431.

49. Park Y, Ayoko GA, Horváth E, Kurdi R, Kristof J, Frost RL. Structural characterisation and environmental application of organoclays for the removal of phenolic compounds. J. Colloid Interface Sci. 2013;393:319-334.

50. Park Y, Sun Z, Ayoko AG, Frosta RL. Bisphenol A sorption by organo-montmorillonite: Implications for the removal of organic contaminants from water. Chemosphere 2014;107:249-256.

51. Nagasaki S, Nakagawa Y, Tanaka S. Sorption of nonylphenol on Na-Montmorillonite. Colloid. Surf. A. Physicochem. Eng. Asp. 2004;230:131-139. 